\title{
Improving teaching practice through Indigenous learning models
}

\section{Introduction}

As an educator learning theories, frameworks and models play an important role when achieving learner success. An educator's flexibility and blended teaching skills can make all the difference when challenged with a class of diversity and various learning abilities. In this essay three learning theories will be discussed along with how it is applied within a learning situation. A comparison of the theories will discuss the similarities and differences, followed by a personal reflection of the significance within a teaching practice.

\section{Te Whare Tapa Whā}

In 1984 Professor Sir Mason Durie developed the renowned health model 'Te Whare Tapa Whā'. At the time this research was undertaken in response to the issues and barriers Māori were experiencing in health. The declining health status for Māori was due to their experiences amongst health practitioners and the lack of spiritual recognition and perceived racism that led to Māori disengagement. It became the conceptual framework to support health practitioners and was a useful lens to think about health, as a whare (Tāne Ora Alliance, 2020). Te Whare Tapa Whā is a holistic health and wellbeing model which displays the four pou of Māori health: 
- Te taha hinengaro (mental and emotional wellbeing)

- Te taha wairua (spiritual well-being)

- Te taha tinana (physical well-being)

- Te taha whānau (family well-being) (Durie, 1994).

Each pou rely upon one another to form structure and stability for the whare. This metaphor is a representation of one's holistic well-being. Te Whare Tapa Whā provided a much-needed health perspective on ways of understanding and engaging with Māori for Māori; and for spirituality to be more readily acknowledged (Tāne Ora Alliance, 2020).

Within the education sector Te Whare Tapa Whā, is vital in the teaching space. Group activities within the classroom environment can foster and encourage positive relationships within small intimate groups, that are practical, communicative, interactive and nondiscriminatory. It draws upon each learners' strengths and highlights areas that are challenging, where the group must work together to achieve. This ako strategy can be linked to all four pou but most importantly Te taha whānau; allowing the learners to build a rapport and be a part of a collective that is nurturing and considerate to their values and beliefs. By supporting all the learners to develop a self-awareness, the educator can improve learner wellbeing and engagement.

\section{Fonofale}

1984 saw the development of the Fonofale model created by Dr Fuimaono Karl Pulotu-Endemann. Through many changes and iterations, the model raised the need of awareness amongst Pacific people and what they believed to be the major determinants of their health. In 1995 with support from the Ministry of Health and Ministry of Pacific Island Affairs the model was published covering the needs expressed by various Pacific Islands (Pulotu- 
Endemann, 2009). The model incorporates the values and beliefs of Pacific peoples relating to HIV/AIDS, sexuality and mental health, furthermore the research from these Pacific communities outlined the most important things included family culture and spirituality (Pulotu-Endemann, 2009). The fonofale model today is a commonly used Pasifika model of health that draws on the metaphor of a Samoan fale / house to represent holistic Pacific values and beliefs:

- Base foundation represents 'aiga (family)

- Roof represents culture

- The four pou (posts) represent: spiritual, physical, mental and other (age, gender etc) dimensions; notions of time, environment and context encircle the fale (Ministry of Education, 2018).

The fonofale model is unique as the all the elements that formulate the structure of the fale are interrelated and rely upon one another. Although this model was developed for the purpose of Health and well-being, this model has been further applied within an education environment.

For the beginning of an education learning session, the educator in the space has the opportunity to acknowledge the spiritual wellbeing of the learners; irrespective of their race, religion or cultural background a prayer (lotu or karakia) is effective; as it acknowledges an existence that protects and nurtures every individual in the classroom. The act of a prayer acknowledges and demonstrates a holistic pedagogy that can be linked to the cultural, spiritual, mental and environment elements of the fonofale model.

\section{Talanoa}

Talanoa is widely used amoungst scholars as a research methodology, Talanoa as stated by Dr Timote Vaioleti is 
a traditional method of story sharing and information gathering where the data collection becomes 'a conversation, a talk, an exchange of ideas or thinking' (Vaioleti, 2006, p.23). Tala means to inform, tell, relate and command, as well as to ask or apply. Noa means of any kind, ordinary, nothing in particular, purely imaginary or void. Talanoa, then, literally means talking about nothing in particular, and interacting without a framework (Vaioleti, 2006). Talanoa is almost always carried out face-to-face, and can be referred to as a conversation, a talk, an exchange of ideas or thinking, whether formal or informal. The methodology of Talanoa is applied in research as a culturally appropriate way of communicating with Pasifika. Vaioleti (2006) further explains that Talanoa is an appropriate method of enquiry as it incorporates the holistic nature and practices of Pacific communities and interaction. Talanoa as a framework can occur in different forms from informing to interviewing, critical discussion and evaluation (Ministry of Education, 2018).

Within education Talanoa is important because it can form a community within the classroom; that fosters and demonstrates learning through conversation and builds relationships where all contributions are valued. When learners are given the opportunity to present they are tasked with the skill of speaking, however, when this is paired with the feedback they are also encouraged to listen with intent. As frightening as this may be for most learners Talanoa helps stimulates the curiosity of the learner. The communication of talanoa can draw upon the leaners lived experiences and challenges them to use and apply what they know in a new context.

\section{Comparison}

Of the three learning frameworks presented the most important similarity that connects the models are that they are all indigenous and are grounded upon indigenous cultural values. The values of family, 
spirituality, physical and mental well-being are prominent stand out factors that interrelate between Te Whare Tapa Whā and Tapasa. Although it is not explicit within the theory of talanoa, the cultural values Talanoa draws upon and is founded within; are based on the principles of Te Whare Tapa Whā and Tapasa.

The frameworks are individually different as they allow a unique way of approaching learner needs from a different perspective. The way that an educator would approach an elder Samoan learner in a space will differ to the way they will approach a Korean exchange student with a learning disability. These differences are important to note and recognise as an educator.

\section{Reflection}

Upon reflection these theories, frameworks and models are useful as they enable myself as the educator to see the world through various lenses, and to have tools that are culturally appropriate and effective to improve the learning wellbeing of my learners. Most models are ethnic-specific but can be adaptable to other groups, as there are shared values and principles that can be applied; when taking initiative to research and talanoa with communities. Some of the models are Fonofale, Fa'afaletui (Samoan), Te Vaka (Tokelau Island), Tivaevae (Cook Islands), Popao, Kakala, Fonua (Tongan). Some are based on metaphors while some are based on natural reality, therefore no one model provides all the solutions. It is important to understand that these theories, frameworks and models do not adequately cover all aspects of learner needs but all contribute some relevance. 


\section{References}

Durie, M. (2003, March). Mãori educational advancement at the Interface between te ao Mãori and te ao whanui. [Paper presentation] Hui Taumata Matauaranga Tuatoru, Turangi/Taupo, New Zealand.

Durie, M. (1994). Whaiaora-Maori health development. Auckland, NZ: Oxford University Press.

Ministry of Education. (2018). Tapasā: Cultural competencies framework for teachers of Pacific learners. Ministry of Education New Zealand Te Tāhuhu o te Mātauranga. https://pasifika.tki.org.nz/Tapasa

Moorfield, J. C. (2011). Te Aka-Māori-English, EnglishMāori dictionary. Auckland, New Zealand: Pearson.

Pulotu-Endemann, F. K. (2009, September 7-9). Fonofale Model of Health [Paper presentation]. Pacific models for health promotion, Wellington, New Zealand. https://whanauoraresearch.co.nz/wpcontent/uploads/formidable/Fonofalemodelexplan ation 1-Copy.pdf

Tāne Ora Alliance. (2020, June 15). Te Whare Tapa Whā - Health as a Whare.

https://www.maorimenshealth.co.nz/te-wharetapa-wha-health-whare/

Vaioleti, T. M. (2006). Talanoa reserch methodology: a developing position on pacific research. Waikato Journal of Education, 12, 21-34. https://researchcommons.waikato.ac.nz/bitstrea $\underline{\mathrm{m} / \text { handle/10289/6199/Vaioleti\%20Talanoa.pdf }}$ 